
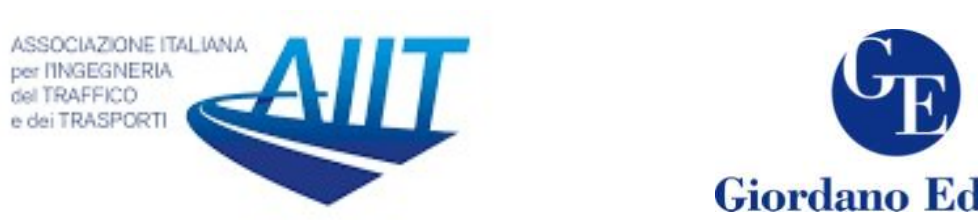

Giordano Editore

\title{
A Sustainable Framework for the Analysis of Port Systems
}

\author{
Matteo Ignaccolo ${ }^{1}$, Giuseppe Inturri, Nadia Giuffrida ${ }^{1 *}$, Vincenza \\ Torrisi $^{1 *}$
}

\author{
${ }^{1}$ Department of Civil Engineering and Architecture, University of Catania, Viale Andrea Doria, 6, \\ Catania 95125, Italy \\ ${ }^{2}$ Department of Electric, Electronic and Computer Engineering, University of Catania, Viale Andrea \\ Doria, 6, Catania 95125, Italy
}

\begin{abstract}
The commercial and industrial growth of the urban areas with consequent specialization of the maritime and land traffic deeply modified in the last centuries the spatial and functional relationship between port and city. Ports became a complex of functions and interactions with the city sharing its commercial, recreational, tourist, cultural, urban spaces and places for leisure. In addition to goods heavy traffic, the new port configuration also attracts important flows of people linked to the cruise sector, passenger traffic and tourism. This mix of activities, while inducing a great potential for transformation and strong changes on the urban economy, generates several externalities on the urban mobility system, such as congestion, accessibility, security and safety issues.

The objective of this paper is to propose a framework for actions and measures to foster sustainability in ports. International best practices for passenger and freight port transport have been analysed with a focus on advantages and disadvantages of already implemented procedures, both in the short and in the long term. Most performing measures have been included in the framework, which classify them according to the three pillars of sustainability and the Avoid-Shift-Improve approach.

The paper clearly defines the key elements needed to be taken into account when demonstrating efficiency of port systems. The methodology can be considered suitable in order to support decision making processes of port management entities and local policy makers regarding the assessment of different alternatives in the short and in the long period.
\end{abstract}

Keywords: Transport planning; Port optimization; Port sustainability; Port-city relationship; Intelligent Transport Systems.

\footnotetext{
* Corresponding author: Nadia Giuffrida (nadia.giuffrida@dica.unict.it) Vincenza Torrisi (vtorrisi@dica.unict.it)
} 


\section{Introduction}

In the last years, with the recent increase of maritime international trade and goods flows, ports have diversified and qualified their operations in order to support the growth of local businesses. They have become the engine of economic growth in coastal cities, changing their role in the economic system from simple landings to commercial centres and generating several thousands of jobs directly connected with the port operation (Kotowska, 2016, Ignaccolo et al., 2018, 2020a). The activities of such industrial and logistics centres also contribute significantly to pollution in coastal urban areas (Marine Insight, 2011), to the point that environmental issues are continuously emerging and becoming a competitive factor among ports (Sislian et al., 2016). Maritime transport is in fact a contributor to global CO2 emissions - almost tripled between 1925 and 2002 (OECD, 2010) - and to SOx and NOx emissions (Dore, 2006, Doudnikoff, Lacoste, 2014; De Meyer et. al., 2008; Hongisto, 2014). The externalities to which port cities are exposed are not only due to operations in the harbour, but also to the increase of road transport caused by handling operations in the hinterland (Viana et. al., 2014). This includes the traffic connected with production and consumption of goods (Lindholm \& Behrends, 2012) and the traffic generated by the transhipment operations in the port, both characterized by delivery trucks flows (Rodrigue et al., 2006). Besides, maritime trades are expected to grow in the following years, and forecasts show that, without a significant environmental improvement, maritime emissions are expected to further increase (Smith et al., 2014).

Port Authorities are responsible for managing the landside and seaside of ports, so they can play, together with operating companies, a proactive role in promoting the protection of the environment and the sustainable development of ports. They must govern in an innovative way according to the economic and environmental principles of sustainability, adjusting the operations within the port to the new requirements, while promoting regional economic impact of the ports; they should contribute to the development of sectors such as the tourist and cultural reception, thanks to the great potential of transformation of city areas located close to ports (Ignaccolo et al., 2019a). Moreover, Port Authorities must act as community managers, finding the compromise among the several port stakeholders to improve collaboration and port performance (Verhoeven, 2010; Acciaro et al., 2014a). Furthermore, if one single port authority can address planning and operation of several ports, optimization and performance can be increased through an effective division of tasks.

The objective of this paper is to investigate approaches and strategies to foster port sustainable development, aiming at pursuing of economic prosperity, environmental quality and social responsibility (Panayides, 2006). Port critical issues have been identified and strategies have been selected from best practice analysis. The identified port actions promoting sustainability have been framed according to an AS-I (Avoid Shift Improve) approach (Deutsche GIZ, 2015). The constructed framework is aimed at supporting port management bodies and local administrators in the search for solutions that ensure the efficiency of port activities but which guarantee port sustainability. 


\section{The A-S-I approach and its relationship with sustainability paradigm}

The term 'sustainable development' first gained a major prominence in the report Our Common Future, published by the World Commission on Environment and Development, which is also commonly known as the Brundtland Report. Its definition is still widely used today: "Sustainable development is a development that meets the needs of the present without compromising the ability of future generations to meet their own needs" (Brundtland, 1987).

The methodology used in this study is based on the concept of sustainability, which is articulated in its three economic, social and environmental aspects, as shown in Figure 1 (WCED, 1987). The strategy of the EU for sustainable development is based on the principle that the economic, social and environmental effects of all policies should be examined in a coordinated way and taken into account in decision making (European Commission, 2001). This recognizes that in the long term, economic growth, social cohesion and environmental protection must go hand in hand (Wolff, 2004). Transport systems in a sustainable society need to fulfil the principles just defined above. A sustainable transport system then contributes economic growth and social equity without systematically increasing concentrations of substances in the atmosphere and degrading nature (Behrends et al., 2008). In particular, in the case of port sustainability, the economic perspective should grant returns on investment, efficiency and maximization of port companies' performance while the social scope should be a direct contribution to employment in port related activities and the assurance of the liveability of the surrounding areas (Sislian et al., 2016); moreover port authorities should ensure a sustainable environmental performance and management regarding noise pollution, air quality, dredging operations and disposal (UNCTAD, 2009).

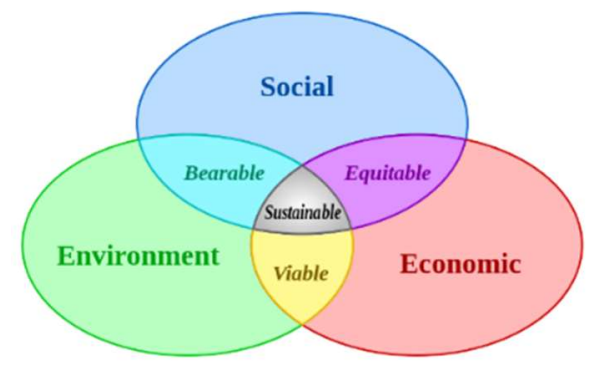

Fig. 1. Sustainability paradigm (WCED, 1987)

Source: WCED, 1987 
Inspired by the principles of sustainability, in this paper the A-S-I (Avoid/Reduce, Shift/Maintain, Improve) approach (Figure 2) has been declined into some actions and measures to be implemented in port areas, seeking to achieve significant air pollution reduction, congestion reduction, with the final aim to contribute to the creation of a more liveable city.

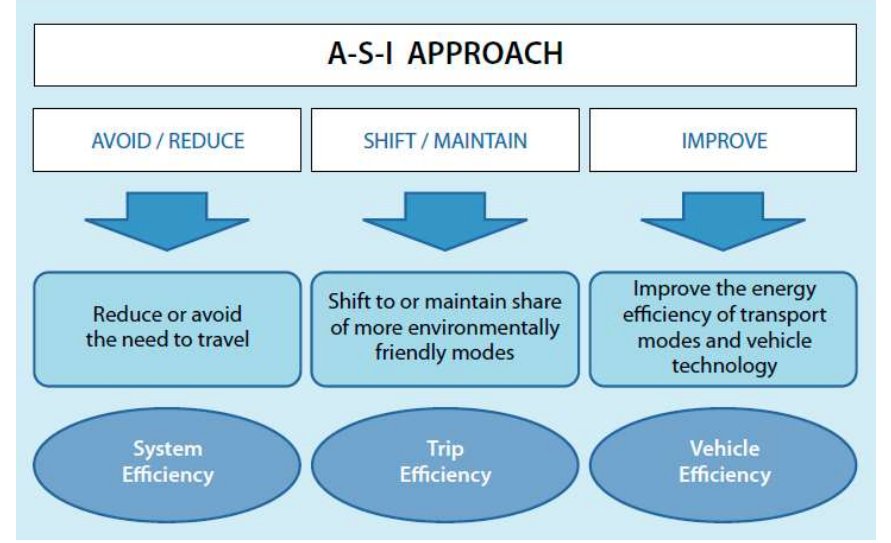

Fig. 2. A-S-I approach (Deutsche GIZ, 2015)

Source: Deutsche GIZ, 2015

Several actions can be implemented in port areas in the framework of the A-S-I approach:

- Avoid - Actions aimed at reducing the demand as far as possible;

- Shift - Actions and measures aimed at the improvement of trip efficiency;

- Improve - Actions and measures focusing on vehicle and fuel efficiency as well as on the optimization of transport infrastructure.

\section{A framework for the application of A-S-I approach to port systems}

\subsection{Framework construction}

The construction of the framework has followed the following steps:

- Analysis of critical issues within the port context

- Analysis of related best practices

- Strategies to be included in the A-S-I framework

\subsection{Analysis of critical issues within the port context}

The main challenges that port managers have to face are due to recent technological innovations in the industrial world and the globalization of trade, which led to a strong need for expansion port areas and specialization of tailored services. Meanwhile, port areas have often become public spaces shared by citizens enjoying the waterfront of their cities and a strong need on possible integration has emerged in port cities. This relationship is often heavily penalized by the presence of physical, visual or infrastructural barriers (walls, road or railway infrastructures), with the consequent lack of connection with the sea front; moreover, the transport system and traffic flows along the external port perimeters further hinder this relationship, often generating e traffic flows of goods and people sharing the same infrastructures and public spaces. Due to these reasons, a search for solutions to improve the coexistence and sharing of spaces between ports and cities that support the administrations of the two entities is needed.

Based on these premises, main port-related critical issues have been classified in relation with the three sustainability pillars (Table 1 ). 
Table 1: Port-related critical issues classification.

\begin{tabular}{lc}
\hline \multicolumn{1}{c}{ Critical issues } & Sustainability dimension \\
\hline C1. Port internal logistics system & Economic; Environmental \\
\hline C2. Freight accessibility & Environmental; Social \\
\hline C3. Application of innovative technologies and ICT & Economic; Environmental \\
\hline C4. Port environmental management systems & Environmental \\
\hline C5. Stakeholder engagement in planning processes & Social \\
\hline C6. Integration between city and port planning & Environmental; Social \\
\hline C7. Pedestrian and bicycle accessibility & Economic; Social \\
\hline
\end{tabular}

Source: own elaboration

\subsection{Analysis of best practices}

Three decades ago, ports were generally regarded as homogeneous entities that competed with each other at different operational levels. In the course of the 1990s, however, the "port product" increasingly came to be seen as a set of interlinking functions, with the port as such serving as one of the links in the overall logistic chain (Musso et al., 2013). Following, a comprehensive list of current practices, that could be labelled as good, have been identified, with the aim to examine the best practices that are necessary in any 'ideal port' from a sustainable perspective.

The practices might refer to different stages that can be linked to decision-making processes related to port or city planning and involve multiple actors both from public and private sector. In fact, even if the decisions regarding the planning of areas and activities are ultimately the responsibility of the port authority (and in some cases of city policy makers), there are several stakeholders in the port sector having their own interests and objectives, sometimes not coherent with sustainability strategy. Shippers are firms that produce and organize freight movements to explore the potential economic benefit from the price differences between different regions. Carriers are firms (i.e. transportation companies or third Party Logistics Service Providers) that operate transportation facilities and provide transportation services. Carriers are divided into ocean carriers, land carriers and port terminal operators according to the physical freight transportation network. Typically, shippers choose a carrier or a sequence of carriers to deliver their products. Port Authorities determine the regulation and provision of transportation infrastructure by investigating the behaviour of carriers and shippers and expecting resulting effects, while their decisions bring about the carriers and shippers' reactions (Lee and Park, 2016).

In addition to internal stakeholders (the same port authority, its employees, unions, shareholders, board members) and local policy makers/legislators, actors of the decision making process include both external and community stakeholders: transport and terminal operators, forwarding and shipping agencies and industrial companies among the firsts; community groups, civil society organizations and the press among the seconds (Notteboom and Winkelmans, 2002). External stakeholders are among the main players in the port economic process, capable of changing the port's role in the global market; while some community stakeholders may become aware of their relationship to the port when an unfavourable event draws their attention (Wagner, 2017). These considerations also make one understand the 
importance of the time factor of the implemented actions: while actions with a shortterm time horizon can have rapid positive impacts while actions with a short-term time horizon can have rapid positive impacts (with small investments and few changes in the state of affairs), long-term impact actions must be illustrated in all their benefits to the stakeholders, in order to guarantee a more conscious acceptance of measures that foresee a greater use of economic resources and modifications of the current structures. Best practices have been selected based on the participation in successfully European Project or high positions placement in international port rankings. The main sources of analysis of best practices were:

- The European project PORTA, PORTs as a gateway for Access inner regions (PORTA project outline);

- The European project PORT INTEGRATION, Multi-modal Innovation for Sustainable Maritime \& Hinterland Transport Structures (PORT INTEGRATION project outline);

- The 2018 edition of Lloyd's List's One Hundred Container Ports (Lloyd's List 2018).

Further information on selected ports have been retrieved from the following sources:

- Reports and statistics from institutional websites;

- Studies and scientific publications on innovative elements and procedures.

To take due account of the complex and heterogeneous nature of ports, the selected best practices were classified according exogenous and endogenous variables. As it possible to see in Table 2, the two exogenous considered variables are represented by the country and location specification of ports, because successful ports belong to successful chains and this means that the competitiveness of individual ports depends not only on their own strengths, but also on those of other links in the chain.

There are examples of ports located at open sea and accessible to the largest seagoing vessels that nonetheless lose some of their competitive edge due to, for example, inadequate hinterland connections (Musso et al., 2013). One endogenous variable taken into consideration for the classification of selected ports was their throughput, which is a standard measure for the productivity of seaports, measured by twenty-foot equivalent units (TEU) handled over a period of time, generally corresponding to a year. Moreover, according to the classification of critical issues reported in Table 1, a set of strategic variables was identified and, for each of these port best practices, one or more strategic variables were highlighted (see Table 2).

Starting from identified critical points, some evidences of port best practices have been denoted, identifying seven clusters of strategies to face these issues (Table 3). 
Table 2: Identification of Port best practices

\begin{tabular}{|c|c|c|c|c|c|}
\hline Port & Country & Location & $\begin{array}{c}\text { Throughput } \\
2017\end{array}$ & Strategic variable & $\begin{array}{c}\text { Source of } \\
\text { information }\end{array}$ \\
\hline Shanghai & China & Yangtze Delta & 40,233 & Capacity; Productivity & $\begin{array}{c}\text { IAPH, } 2017 \\
\text { Hu et al., } 2011\end{array}$ \\
\hline Singapore & Singapore & Malacca Strait & 33,666 & Capacity; Productivity & $\begin{array}{c}\text { IAPH, } 2017 \\
\text { PSA Singapore. } \\
\text { MPA Singapore, } \\
2017 . \\
\end{array}$ \\
\hline Rotterdam & Netherlands & North sea & 13,734 & $\begin{array}{c}\text { System integration; } \\
\text { Tech./Env. innovations } \\
\text { Prices; Cooperation }\end{array}$ & $\begin{array}{c}\text { IAPH, } 2017 \\
\text {; Port of Rotterdam, } \\
2018\end{array}$ \\
\hline Honk Hong & China & $\begin{array}{c}\text { Pearl River } \\
\text { Delta }\end{array}$ & 20,770 & $\begin{array}{l}\text { Technological } \\
\text { innovation }\end{array}$ & $\begin{array}{c}\text { IAPH, } 2017 \\
\text { BTM Asia Pacific, } \\
2014 . \\
\text { HKMPB. }\end{array}$ \\
\hline Antwerp & Antwerp & North sea & 10,451 & System integration & $\begin{array}{c}\text { IAPH, } 2017 \\
\text { Port of Antwerp, } \\
2017\end{array}$ \\
\hline Marseilles & France & Gulf of Lion & 1,251 & Cooperation & $\begin{array}{c}\text { Flemish Port } \\
\text { Commission } \\
\text { Marseilles fos. Port } \\
\text { of Marseilles, } 2016\end{array}$ \\
\hline Amsterdam & Netherlands & Markermeer & 0,515 & $\begin{array}{c}\text { Env. innovations; } \\
\text { Prices; , Cooperation; } \\
\text { Requalification }\end{array}$ & $\begin{array}{c}\text { Flemish Port } \\
\text { Commission } \\
\text { Port of } \\
\text { Amsterdam, } 2017 .\end{array}$ \\
\hline Koper & Slovenia & Gulf of Trieste & 0,487 & System integration & $\begin{array}{c}\text { Portseurope, } 2018 \mathrm{a} \\
\text { Trupac and Twrdy, } \\
2010 \\
\text { ESPO, } 2016 \\
\end{array}$ \\
\hline Gijón & Spain & Cantabrian Sea & 0,076 & Integrated planning & $\begin{array}{c}\text { Flemish Port } \\
\text { Commission } \\
\text { Puerto de Gijon, } \\
2017\end{array}$ \\
\hline Barcelona & Spain & Balearic & 3 & Integrated planning & $\begin{array}{c}\text { Flemish Port } \\
\text { Commission } \\
\text { Puerto de } \\
\text { Barcelona, 2017 }\end{array}$ \\
\hline Malaga & Spain & Alboran Sea & 0,296 & Infrastructure & $\begin{array}{c}\text { Puerto de Malaga, } \\
2017\end{array}$ \\
\hline Alicante & Spain & $\begin{array}{c}\text { Mediterranean } \\
\text { Sea }\end{array}$ & 0,160 & Infrastructure & $\begin{array}{c}\text { Portseurope, } 2018 b \\
\text { Puerto de Alicante, } \\
2017\end{array}$ \\
\hline
\end{tabular}

Source: own elaboration 
Table 3: Port best practices' classification.

\begin{tabular}{cll}
$\begin{array}{c}\text { Critical } \\
\text { issues }\end{array}$ & \multicolumn{1}{c}{ Port best practices } & \multicolumn{1}{c}{ Strategies } \\
C1. & Shanghai - Singapore & S1.1 Optimum use of space; \\
& & S1.2 Facilities and equipment for routing improvement; \\
& S1.3 Efficient gate assignment and processing system. \\
\hline C2. & Koper - Antwerp - Rotterdam & S2.1 Infrastructure utilization to minimize congestion \\
& & S2.2 Reduction in road transport \\
\hline C3. & Honk Hong - Rotterdam & S3 Pre-custom clearance of international freight \\
\hline C4. & Amsterdam - Rotterdam & S4.1 Reducing the number of trips performed by gasoline \\
& & vessels; \\
& & S4.2 Use of CNG, bio-Diesel, hydrogen fuel and production \\
& & of renewable energy \\
\hline C5. & Amsterdam - Rotterdam & S4.3 Introduction of charges and taxes \\
& & S5.1 Collaboration among ports' actors; \\
C6. & Amsterdam - Gijón - & S6.2 Information campaign \\
& Barcelona & city-port plan integration \\
\hline C7. & Malaga -Alicante & S6.2 Waterfront requalification \\
\hline Source: Own elaboration. & S7 Safety measures for no motorized traffic \\
\hline
\end{tabular}

Best practice for $C 1$. Port of Shanghai is the first in the top fifty global container ports, followed by the port of Singapore ${ }^{1}$. They perform the important role of $h u b$, where containers from one-liner service are transferred to another one for on-carriage to their final destination. This huge quantity of goods needs wide storage and handling spaces and an optimized organization of operations in order to guarantee an efficient ship and cargo movement; moreover, in the case of ro-ro traffic, to minimize environmental externalities related to heavy vehicles, facilities and equipment can be used to enhance vehicle routing inside the port and in the neighbouring areas (Calabrò et al. 2020), also making use of technological support, such as sensors for traffic detection (Torrisi et al., 2016). Such ports handle a variety of freight traffic and there are multiple ways to measure port efficiency. In recent years a measure of active container-ports is their throughput, measured in TEUs/year.

Best practice for $C 2$. A good accessibility to hinterland is fundamental, since most businesses and consumers are located outside the port area. Goods can be moved both via truck or rail from their origin to their destination. This means that freight movement requires an intermodal network, characterized by the integration of different transport modes, including the infrastructure and the connections or transfer points between the modes, often referred to as intermodal connectors. Service disruption or insufficient capacity anywhere in the network could result in shipment delays and increased cost (World Shipping Council, 2019). Port of Koper is a best practice for road accessibility, presenting a high number of road accesses in respect of its perimeter. This represents an indicator for improved traffic flow in the area adjacent to the port because a greater number of accesses reduces the phenomenon of congestion. In addition, the port area can be related to the amount of the port commercial activity: so a great number of accesses proportionate to this area has an impact on freight traffic volumes on road connections to the port. Similar consideration can be made as far as the traffic of goods by rail is concerned, examining the number of intermodal terminals and tons of goods by rail. Ports of 
Antwerp and Rotterdam have a good level of connection to the TEN-T network (Trans-European Networks - Transport), which guarantees a direct link to the major European cities through all transport modes .

Best practice for C3. In order to improve traffic performances, definitely the application of innovative technologies can be a fundamental support (Torrisi et al., 2018a, 2018b). Information and communication technologies (ICT) are systems required for the port connectivity. Companies participating in the port community develop appropriate strategies to achieve a proper choice for the integration of special technologies and intelligent transport systems (ITS) in order to optimize their performances. In fact, the ever-increasing demand for sea transport, effectively involves enhancing the attention to systems capable of "intelligently" addressing the mobility problems in their entirety (Torrisi et al., 2018c), by allowing more effective and efficient overall performance of the system (Torrisi et al., 2017a, 2017b). According to Chinese ITS development experience, attitudes and policies of the government are important for ITS technologies innovation and industrialization, and a well-designed framework and planning with their own need is important premises for the ITS development for a country. Indeed, in the Chinese context, it has just started a large-scale construction of road infrastructure, and ITS was considered as a future and expensive tool box. Port of Hong Kong represents a best practice in this context. In the European scenario, Port of Rotterdam can be considered thanks to the high degree of computerized customs procedures.

Best practice for $C 4$. In the context of maximizing port efficiency, also through the use and application of new technologies, surely an important aspect to be taken into consideration is the issue of environmental pollution (Giuffrè et al. 2017). Ships produce carbon dioxide emissions that contribute to global climate change like all modes of transportation that use fossil fuels, besides producing other pollutants that contribute to the problem. Moreover, the ship's waste, the noise pollution caused by the vessels and the erosion of the coast in adjacent areas to the port infrastructure are relevant hardest questions. Specialist regulations, conventions and guidelines underpin each operation which may have an impact on environmental aspects including emissions to air, soil and sediments, discharges to water, noise, waste production, changes in terrestrial habitats and marine ecosystems, odour, resource consumption and port development on land or sea. Typical of many industries, ports adopted a combination of awareness training and tougher regulation to bridge a gap between environmental aspirations and practice (Dinwoodie et al., 2012). In this direction, port of Amsterdam has carried on an optimization of port spaces in order to limit the visual intrusion, reducing navigation risks related to maritime traffic and the number of vessels carrying hazardous goods. Port of Rotterdam has implemented port environmental management systems for water cleaning and for energy production from renewable sources (i.e. Off Shore wind turbines and photovoltaic panels).

Best practice for $C 5$. In most cases port authorities are responsible of port development and the master plan is a medium-long term plan which establishes the strategic planning of the port. It provides a clear vision regarding how the port will be developed considering the time horizon and showing the potential of the surrounding community. Nowadays, the elaboration of a port masterplan is customary. Giving the opportunity to stakeholders to express their opinions and expectations is a key part of the process (Cascetta, 2013; Le Pira, 2018, Ignaccolo et 
al., 2019b). For this reason, during the elaboration of the master plan, port authorities should involve key stakeholders: representatives of public administration, citizens, non-governmental organizations (ONG); employees' representative, etc. It is possible to identify different levels of participation: implementation of actions, co-production, choice of alternatives, or information. Ports of Amsterdam and Rotterdam can be considered best practices from the point of view of stakeholder engagement in planning processes with a high degree of participation through the establishment of thematic meetings and information campaigns.

Best practice for C6. Another obstacle to a more inclusive planning policy may be related to land use conflict between the public interest of the Port Authority and Municipality and the private interest of port operators. Therefore, the need for a cityport plan integration is outlined as a central planning issue so as to combine the economic development of the port with social, cultural and ecological themes. In this context, it is fundamental to involve all stakeholders in a participation process which could take advantage of the spatial information provided by each actor based on their own data and planning wishes (Giuffrida et al., 2019)

Port of Amsterdam has implemented visible actions constituted by a delocalization of traffic process in favour of the development of areas for multi-purpose recreational centres. The city of Barcelona is characterized by numerous connections by road and by rail, which make the port a key hub for the economy of the entire Mediterranean. In order to promote a port-city integration, commercial activities have been transferred to other sites to decrease the intense vehicular traffic in the bordering areas. In this way, the port has been transformed an intermodal node and a waterfront requalification was promoted through the construction of multi-purpose recreational centres, structures dedicated to cultural events and exhibitions areas.

Best practice for $C 7$. The interaction between operations related to freight traffic and recreational activities inside the port pose important safety issues for nonmotorized users, who often share spaces with heavy industry activities. In this context, it is fundamental the creation of large spaces, pedestrian and cycle paths (Ignaccolo et al., 2018, Ignaccolo et al., 2020b) and several interventions to improve the accessibility of the port and the safety of no motorized users. Accessibility can also be considered a good indicator of social inclusion (Giuffrida et al, 2017, 2018), which allows to evaluate the port also from the point of view of the redevelopment of public spaces. Port of Malaga has realized the pedestrianization of some areas and the construction of recreational centres to improve port-city integration. Furthermore, part of the city's cycle network makes the port easily accessible and to incentive the pedestrian access to the port area, attractive facilities and a pedestrian promenade have been planned. Port of Alicante has also a good accessibility because it is easily reachable by pedestrians and cyclists coming from the railway station near to the city centre through tree-lined avenues which connect the two services. In addition, Alicante's bus station is located inside the port and it daily receives a large number of passengers from the different provinces of Spain.

In Table 4 the allocation of the selected strategies to proper stakeholder is presented, providing also the decision-making body and a stakeholder classification in the four groups presented in section 3.3: (i) internal, (ii) external, (iii) legislation and public policy and (iv) community stakeholders. 
Table 4: Classification of strategies according to time horizon and involved stakeholders.

\begin{tabular}{|c|c|c|c|}
\hline Strategy & $\begin{array}{l}\text { Reference } \\
\text { body }\end{array}$ & Time Horizon & Stakeholders \\
\hline S1.1. Optimum use of space & Port & $\begin{array}{l}\text { Short/Mid } \\
\text { Term }\end{array}$ & Internal and external \\
\hline $\begin{array}{l}\text { S1.2. Facilities and equipment for } \\
\text { routing improvement }\end{array}$ & Port & $\begin{array}{l}\text { Short/Mid } \\
\text { Term }\end{array}$ & Internal and external \\
\hline $\begin{array}{l}\text { S1.3. Efficient gate assignment and } \\
\text { processing system }\end{array}$ & Port & $\begin{array}{l}\text { Short/Mid } \\
\text { Term }\end{array}$ & Internal and external \\
\hline $\begin{array}{l}\text { S2.1 Infrastructure utilization to } \\
\text { minimize congestion }\end{array}$ & Port/City & $\begin{array}{l}\text { Mid/Long } \\
\text { Term }\end{array}$ & $\begin{array}{c}\text { Internal, external, } \\
\text { legislation and public } \\
\text { policy }\end{array}$ \\
\hline S2.2 Reduction in road transport & City & $\begin{array}{l}\text { Mid/Long } \\
\text { Term }\end{array}$ & ALL \\
\hline $\begin{array}{l}\text { S3.1 Pre-custom clearance of } \\
\text { international freight }\end{array}$ & Port & $\begin{array}{l}\text { Short/Mid } \\
\text { Term }\end{array}$ & $\begin{array}{l}\text { Internal, external, } \\
\text { legislation and public } \\
\text { policy }\end{array}$ \\
\hline $\begin{array}{l}\text { S4.1. Reducing the number of trips } \\
\text { performed by gasoline vessels }\end{array}$ & Port & $\begin{array}{l}\text { Mid/Long } \\
\text { Term }\end{array}$ & Internal and external \\
\hline $\begin{array}{l}\text { S4.2. Use of CNG, bio-Diesel, } \\
\text { hydrogen fuel and production of } \\
\text { renewable energy }\end{array}$ & Port & $\begin{array}{l}\text { Mid/Long } \\
\text { Term }\end{array}$ & Internal and external \\
\hline $\begin{array}{l}\text { S4.3. Introduction of charges and } \\
\text { taxes }\end{array}$ & Port/City & $\begin{array}{l}\text { Short/Mid } \\
\text { Term }\end{array}$ & Internal and external \\
\hline $\begin{array}{l}\text { S5.1. Collaboration among ports' } \\
\text { actors }\end{array}$ & Port/City & $\begin{array}{l}\text { Mid/Long } \\
\text { Term }\end{array}$ & ALL \\
\hline S5.2. Information campaign & Port/City & $\begin{array}{l}\text { Short/Mid } \\
\text { Term }\end{array}$ & ALL \\
\hline $\begin{array}{l}\text { S6.1. Inclusive planning policies } \\
\text { related to city-port integration }\end{array}$ & Port/City & $\begin{array}{l}\text { Mid/Long } \\
\text { Term }\end{array}$ & ALL \\
\hline S6.2. Waterfront requalification & Port/City & $\begin{array}{l}\text { Mid/Long } \\
\text { Term }\end{array}$ & ALL \\
\hline $\begin{array}{l}\text { S7.1 Safety measures for no } \\
\text { motorized traffic }\end{array}$ & Port/City & $\begin{array}{l}\text { Short/Mid } \\
\text { Term }\end{array}$ & $\begin{array}{l}\text { Internal and legislation } \\
\text { and public policy }\end{array}$ \\
\hline
\end{tabular}

Source: Own elaboration.

\subsection{Strategies inclusion in the framework}

Based on the analysis of the presented best practices, intervention strategies have been grouped according to the critical issue and a set of indicators has been formulated to assess their impacts, coupled with the three different approaches of the A-S-I scheme, as proposed in Table 4.

- Avoid: Economic Measures (Introduction of charges and taxes), Environmental Measures (Reducing the number of trips performed by diesel oil vessels), Administrative measures (Pre-custom clearance of international freight; Collaboration among ports' actors)

- Shift: Reassignment of traffic to other ports (Infrastructure utilization to minimize congestion); Reassignment of traffic to other transport systems (Reduction in road transport); Provide services in different areas and promote them (Optimum use of space; Information campaign)

- Improve: Vessels technologies (Use of CNG, bio-Diesel, hydrogen fuel and production of renewable energy); Terminal project and operations (Efficient gate 
assignment and processing system; Improvement of existing structures (Facilities and equipment for routing improvement; Inclusive planning policy related to city-port integration); Improvement of port infrastructure fruition (Waterfront requalification; Safety measures for no motorized traffic)

Table 5: Strategies, A-S-I dimension, impacts and proposed indicators.

\begin{tabular}{|c|c|c|c|}
\hline Strategy & $\begin{array}{c}A-S-I \\
\text { dimension }\end{array}$ & Impact & Proposed Indicators \\
\hline S1.1. Optimum use of space & Shift & Economic & I.1.1. TEUs/square metres \\
\hline $\begin{array}{l}\text { S1.2. Facilities and } \\
\text { equipment for routing } \\
\text { improvement }\end{array}$ & Improve & Environmental & $\begin{array}{l}\text { I.1.3. Contaminants and emissions } \\
\text { related to internal heavy traffic flows }\end{array}$ \\
\hline $\begin{array}{l}\text { S1.3. Efficient gate } \\
\text { assignment and processing } \\
\text { system }\end{array}$ & Improve & Economic & I.1.3. Throughput (TEUs/year) \\
\hline $\begin{array}{l}\text { S2.1 Infrastructure utilization } \\
\text { to minimize congestion }\end{array}$ & Shift & Environmental & $\begin{array}{l}\text { I.2.1 Number of road accesses to port } \\
\text { perimeter and port area }\end{array}$ \\
\hline $\begin{array}{l}\text { S2.2 Reduction in road } \\
\text { transport }\end{array}$ & Shift & Environmental & $\begin{array}{l}\text { I.2.2(i) Tons of goods by rail; } \\
\text { I.2.2(ii) Number of intermodal } \\
\text { terminals and railway connections }\end{array}$ \\
\hline $\begin{array}{l}\text { S3.1 Pre-custom clearance of } \\
\text { international freight }\end{array}$ & Avoid & Economic & $\begin{array}{l}\text { I.3.1 Tons of international goods } \\
\text { cleared before the arrival }\end{array}$ \\
\hline $\begin{array}{l}\text { S4.1. Reducing the number of } \\
\text { trips performed by gasoline } \\
\text { vessels }\end{array}$ & Avoid & Environmental & I.4.1 Tons of fossil fuel consumption \\
\hline $\begin{array}{l}\text { S4.2. Use of CNG, bio- } \\
\text { Diesel, hydrogen fuel and } \\
\text { production of renewable } \\
\text { energy }\end{array}$ & Improve & Environmental & $\begin{array}{l}\text { I.4.2(i) Number of vessels equipped } \\
\text { with clean engines } \\
\text { I.4.2(ii) Renewable energy } \\
\text { production in MW }\end{array}$ \\
\hline $\begin{array}{l}\text { S4.3. Introduction of charges } \\
\text { and taxes }\end{array}$ & Avoid & Economic & I.4.3 Revenues/tons of goods \\
\hline $\begin{array}{l}\text { S5.1. Collaboration among } \\
\text { ports' actors }\end{array}$ & Avoid & Social & $\begin{array}{l}\text { I.5.1 Level of community } \\
\text { involvement (among: } \\
\text { implementation, coproduction, } \\
\text { choice, information) }\end{array}$ \\
\hline S5.2. Information campaign & Shift & Social & I.5.2 Number of campaigns/year \\
\hline $\begin{array}{l}\text { S6.1. Inclusive planning } \\
\text { policies related to city-port } \\
\text { integration }\end{array}$ & Improve & Economic & $\begin{array}{l}\text { I.6.1 Urbanization in the surrounding } \\
\text { areas (United Nations, 2014) }\end{array}$ \\
\hline $\begin{array}{l}\text { S6.2. Waterfront } \\
\text { requalification }\end{array}$ & Improve & Social & $\begin{array}{l}\text { I.6.2(i) Area of multi-purpose } \\
\text { recreational centres/Port area } \\
\text { I.6.2(ii) Length of walls/fences } \\
\text { separating port from city }\end{array}$ \\
\hline $\begin{array}{l}\text { S7.1 Safety measures for no } \\
\text { motorized traffic }\end{array}$ & Improve & Social & $\begin{array}{l}\text { I.7.1(i) Cycle path length } \\
\text { I.7.1(ii) Pedestrian accessible } \\
\text { area/Port area }\end{array}$ \\
\hline
\end{tabular}

Source: Own elaboration.

The resulting strategies can be framed into a matrix which contains measures according to their sustainability dimension and type of approach in A-S-I scheme (Fig.3). 


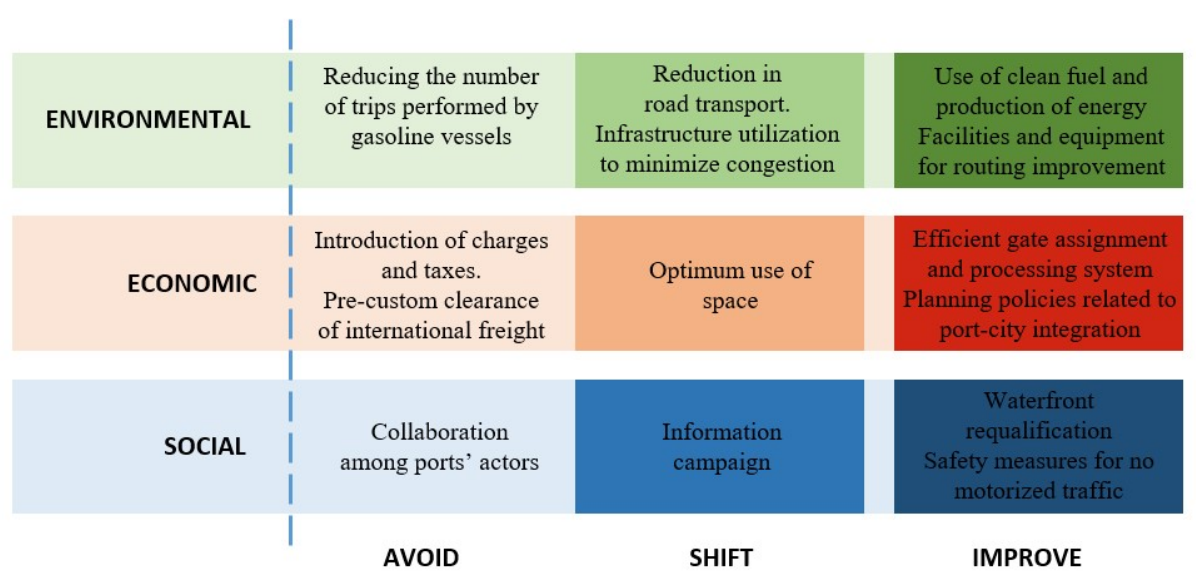

Fig. 3. Framework for classification of port sustainability measures according to type of strategy.

Source: Own elaboration.

Such framework can be used to help decision makers in the choice of measures to solve criticalities in port management and implement specific strategies to promote sustainability in port environment; in addition, the indicators relating to each measure can be used to make a first assessment of the port's sustainability performances.

\section{Conclusion}

Nowadays ports can be considered crucial nodes for economic development of regions, being a main hub for freight handling and acting as facilitators of international trade. The recent increase in goods movement produced conflict elements between ports and their cities and the related economic, social and environmental externalities are generating new port's sustainability issues.

In this study a framework for the selection of measures to improve ports' performances through good practices identification is proposed. Main criticalities have been identified, with a focus on port's logistic, accessibility, use of new technologies, environmental matters, planning and policies and attention to nomotorized users' safety. Best practices from European projects and international rankings have been analysed and adopted measures and actions have been grouped in seven clusters of strategies, classified according to the A-S-I approach and the three sustainability dimensions. Starting from the strategies' definition, a set of corresponding indicators has been drafted in order to assess and monitor their impacts.

Finally, strategies have been framed into an A-S-I/Sustainability matrix, which can be applied as a first-stage tool to aid decision makers in the management and assessment of ports. Further research could focus on detailed definition of the measures and indicators tailored on specific case-study application, and the evaluation of the introduction of a third dimension of the matrix related to the time horizon of application of the actions. 


\section{References}

Acciaro, M., Vanelslander, T., Sys, C., Ferrari, C., Roumboutsos, A., Giuliano, G., Lam, J.S.L., Kapros, S. (2014). Environmental sustainability in seaports: a framework for successful innovation. Maritime Policy \& Management. 41 (5), 480-500.

Behrends, S., Lindholm, M., Woxenius, J. (2008). The Impact of Urban Freight Transport: A Definition of Sustainability from an Actor's Perspective. Planning and Technology, vol. 31:6, pp. 693-713, DOI: 10.1080/03081060802493247

Brundtland, G. H. (1987) Our Common Future: The World Commission on Environment and Development (Oxford: Oxford University Press)

BTM Asia Pacific (2014). Study on the Strategic Development Plan for Hong Kong Port 2030. [online] Available at:

https://www.hkmpb.gov.hk/document/ES_Eng.pdf [Accessed 01/03/2019]

Calabrò, G., Torrisi, V., Inturri, G., \& Ignaccolo, M. (2020). Improving inbound logistic planning for large-scale real-world routing problems: a novel ant-colony simulation-based optimization. European Transport Research Review, 12, 1-11.

Cascetta E., Pagliara F. (2013). Public Engagement for Planning and Designing Transportation Systems, Procedia - Social and Behavioral Sciences, vol. 87, pp. 103-116

De Meyer, P., Maes, F., \& Volckaert, A. (2008). Emissions from international shipping in the Belgian part of the North Sea and the Belgian seaports, Atmospheric Environment, 42(1), 196-206.

Deutsche Gesellschaft für Internationale Zusammenarbeit (giz) GmbH. (n.d.). Sustainable Urban Transport: Avoid-Shift-Improve (A-S-I). [online] Available at: https://www.sutp.org/files/contents/documents/resources/E_Fact-Sheets-andPolicy-Briefs/SUTP_GIZ_FS_Avoid-Shift-Improve_EN.pdf [Accessed 01/03/2019].

Dinwoodie, J., Tuck, S., Knowles, H., Benhin, J., \& Sansom, M. (2012). Sustainable development of maritime operations in ports. Business Strategy and the Environment, 21(2), 111-126.

Dore, A. J., Vieno, M., Tang, Y. S., Dragosits, U., Dosio, A., Weston, K. J., \& Sutton, M. A. (2007). Modelling the atmospheric transport and deposition of sulphur and nitrogen over the United Kingdom and assessment of the influence of SO2 emissions from international shipping, Atmospheric Environment,41(11), 23552367.

Doudnikoff, M., \& Lacoste, R. (2014). Effect of a speed reduction of containerships in response to higher energy costs in Sulphur Emission Control Areas, Transportation Research Part D: Transport and Environment, 27, 19-29.

ESPO. Port of the Month. Port of Koper (Slovenia) (2016). [online] Available at: ttps://www.espo.be/news/port-of-the-month-port-of-koper-slovenia [Accessed 01/03/2019]

European Commission (2001). A Sustainable Europe for a Better World: A European Union Strategy for Sustainable Development (Brussels: Commission of the European Communities).

Flemish Port Commission. Maritime traffic in European ports. [online] http://www.vlaamsehavencommissie.be/en/vhc/thema/maritime-traffic-europeanports [Accessed 04/03/2019]. 
HKMPB. Hong Kong:Your Global Super-connector. [online] Available at: https://www.hkmpb.gov.hk/publications/17.pdf [Accessed 01/03/2019]

Hongisto, M. (2014). Impact of the emissions of international sea traffic on airborne deposition to the Baltic Sea and concentrations at the coastline, Oceanologia, 56(2), 349-372.

Hu, L., X. Shi, S. Voß, and W. Zhang (2011). "Application of RFID Technology at the Entrance Gate of Container Termi-nals.". Computational Logistics: Proceedings of Second International Conference, ICCL 2011, Hamburg, Germany, September 19-22, 6971, 209-220. Berlin: Springer.

IAPH, World Container Traffic Data 2017. [online] https://www.iaphworldports.org/statistics [Accessed 04/03/2019]

Giuffrè, T., Campisi, E. T., Canale, E. A., Severino, A., \& Trubia, S. Traffic Simulator Tool as Reliable Effort for Environmental Estimation at Road Intersection, 2017.

Giuffrida, N., Inturri, G., Caprì, S., Spica, S., \& Ignaccolo, M. (2017). The impact of a bus rapid transit line on spatial accessibility and transport equity: The case of Catania. Transport Infrastructure and Systems. In Proceedings of the AIIT International Congress on Transport Infrastructure and Systems, TIS (pp. 753758).

Giuffrida, N., Ignaccolo, M., Inturri, G., Rofè, Y., \& Calabrò, G. (2017). Investigating the correlation between transportation social need and accessibility: The case of Catania. Transportation Research Procedia, 27, 816-823.

Giuffrida, N., Le Pira, M., Inturri, G., \& Ignaccolo, M. (2019). Mapping with stakeholders: An overview of public participatory GIS and VGI in transport decision-making. ISPRS International Journal of Geo-Information, 8(4), 198.

Ignaccolo M., Inturri G., Giuffrida N., Torrisi V., 2018. Investigating Scenarios for Freight Traffic in the Eastern Sicily Port System. Presented at the 18th International Conference on Transport Science, ICTS2018, Portrož, Slovenia, 14th-15th June, 2018.

Ignaccolo, C., Giuffrida, N., \& Torrisi, V. (2018, July). The queensway of New York city. A proposal for sustainable mobility in queens. In Town and Infrastructure Planning for Safety and Urban Quality: Proceedings of the XXIII International Conference on Living and Walking in Cities (LWC 2017), June 15-16, 2017, Brescia, Italy (p. 69). CRC Press.

Ignaccolo, M., Inturri, G., Giuffrida, N., Cocuzza, E., Torrisi, V. (2019). Framework for the evaluation of the quality of pedestrian routes for the sustainability of portcity shared areas. Coastal Cities and their Sustainable Future III, WIT Transactions on The Built Environment, Volume 188, WIT Press, ISSN 1743-3509.

Ignaccolo, M., Inturri, G., Giuffrida, N., Le Pira, M., \& Torrisi, V. (2019). Public Engagement for Designing New Transport Services: Investigating Citizen Preferences from a Multiple Criteria Perspective. Transportation Research Procedia, 37, 91-98.

Ignaccolo, M., Inturri, G., Giuffrida, N., Torrisi, V., \& Cocuzza, E. (2020). Sustainability of Freight Transport through an Integrated Approach: the Case of the Eastern Sicily Port System. Transportation Research Procedia, 45, 177-184.

Ignaccolo, M., Inturri, G., Giuffrida, N., Le Pira, M., Torrisi, V., \& Calabrò G. (2020). A step towards walkable environments: spatial analysis of pedestrian 
compatibility in an urban context. European Transport - Trasporti Europei, Giordano Editore, 76, 2020..

Kotowska, I (2016). Policies applied by seaport authorities to create sustainable development in port cities. 2nd International Conference "Green Cities - Green Logistics for Greener Cities", 2-3 March 2016, Szczecin, Poland. Transportation Research Procedia 16 (2016) 236 - 243.

Lee, H., \& Park, D. (2016). Conceptual framework and environmental issue in the freight transport system. KSCE Journal of Civil Engineering, 20(3), 1109-1118.

Le Pira, M. (2018). Transport planning with stakeholders: An agent-based modelling approach. International Journal of Transport Economics, 45(1), pp. 17-32.

Lindholm, M., \& Behrends, S. (2012). Challenges in urban freight transport planning-a review in the Baltic Sea Region. Journal of Transport Geography, 22, 129-136.

Lloyd's List Top 100 Ports 2018 | Maritime Intelligence. [online] https://lloydslist.maritimeintelligence.informa.com/one-hundred-container-ports2018 [Accessed 04/03/2019]

Marine Insight (2011). Integrating sustainable development and maritime industry. [online] Available at: http://www.marineinsight.com/marine/integratingcorporate-social responsibility-andmaritime-industry [Accessed 01/03/2019].

Marseilles fos. Port of Marseilles, Annual Report (2016). [online]

MPA Singapore (2017). Sustainability Integrated Report. [online] Available at: https://www.mpa.gov.sg/web/wcm/connect/www/673cebf2-5d1e-49f5-9e876f07af8f0813/MPA+IR+\%26+FR.pdf?MOD=AJPERES\&CACHEID=673cebf25d1e-49f5-9e87-6f07af8f0813 [Accessed 01/03/2019].

Musso, A., Piccioni, C., \& Van de Voorde, E. (2013). Italian seaports' competition policies: Facts and figures. Transport Policy, 25, 198-209.

OECD (2010). Globalisation, Transport and the Enviroment. [online] Available at: $\mathrm{http} / / /$ re.indiaenvironmentportal.org.in/files/globalisation\%20tranport $\% 20$ and $\% 2$ 0the\%20environment.pdf. [Accessed 01/03/2019].

Notteboom T., Winkelmans W. (2002). Stakeholder Relations Management in ports: dealing with the interplay of forces among stakeholders in a changing competitive environment, IAME 2002. Maritime Economics: setting the foundations for port and shipping policies, Panama City.

Panayides, P. (2006). Maritime logistics and global supply chains: Towards a research agenda. Maritime Economics and Logistics, 8(2), 3-18.

Port of Amsterdam. Results for 2017. Annual Report. [online] Available at: https://www.portofamsterdam.com/sites/poa/files/media/pdfen/annual_report_2017_final-online.pdf [Accessed 01/03/2019].

Port of Antwerp, Sustainability Report (2017). [online] Available at:

Port of Rotterdam. Facts and Figures. [online] Available at: https://www.portofrotterdam.com/en/our-port/facts-figures-about-the-port [Accessed 01/03/2019].

PORT INTEGRATION project outline [online] https://rimis.ec.europa.eu/project/multi-modal-innovation-sustainable-maritimehinterland-transport-structures\#tab-outline [Accessed 04/03/2019]

PORTA project outline [online]https://trimis.ec.europa.eu/project/ports-gatewayaccess-inner-regions\#tab-outline [Accessed 04/03/2019] 
Portseurope (2018)a. Koper port - Maritime throughput and revenues in Jan-Jun 2018 [online] https://www.portseurope.com/koper-port-maritime-throughputand-revenues-in-jan-jun-2018/ [Accessed 04/03/2019]Puerto de Alicante. Memoria annual 2017. [online] Available at: https://www.puertoalicante.com/wp-content/uploads/2018/07/Memoria-PuertoAlicante-2017.pdf [Accessed 01/03/2019].

Portseurope (2018)b. Alicante port works to attract container traffic from Valencia. [online] https://www.portseurope.com/alicante-port-works-to-attract-containertraffic-from-valencia/ [Accessed 04/03/2019]Puerto de Barcelona, Memoria annual, 2017. [online] Available at:

Puerto de Barcelona, Memoria annual (2017). [online] http://content.portdebarcelona.cat/cntmng/guestDownload/direct/workspace/Spac esStore/90a0faad-cb00-434c-b5a7-9bbebecb4127/PortBCN memoria2017ES.pdf [Accessed 01/03/2019].

Puerto de Gijon, memoria annual (2017). [online] Available at: https://www.puertogijon.es/wp-content/uploads/2018/08/MEMORIA2017WEB.pdf [Accessed 01/03/2019].

Puerto de Malaga. Memoria annual (2017). [online] Available at: http://www.malagaport.eu/memoria-autoridad-portuaria-de-malaga-201 [Accessed 01/03/2019].

PSA Singapore. Innovation. [online] Available at: https://www.singaporepsa.com/our-commitment/innovation [Accessed 01/03/2019].

Rodrigue, J.-P., Slack, B., \& Comtois, C. (2006). The Geography of Transport Systems. Routledge, Abingdon, Oxon, England; New York.

Sislian, L., Jaegler, A., Cariou, P. (2016). A literature review on port sustainability and ocean's carrier network problem. Research in Transportation Business \& Management 19, 19-26.

Smith, et al. (2014). The Third IMO GHG Study. Imo.org.

Torrisi, V., Ignaccolo, M., Inturri, G., \& Giuffrida, N. (2016). Combining sensor traffic and simulation data to measure urban road network reliability. In International Conference on Traffic and Transport Engineering (ICTTE) Proceedings, Belgrade (p. 1004).

Torrisi, V., Ignaccolo, M., \& Inturri, G. (2017). Estimating travel time reliability in urban areas through a dynamic simulation model. Transportation Research Procedia, 27, 857-864.

Torrisi, V., Ignaccolo, M., \& Inturri, G. (2017). Analysis of road urban transport network capacity through a dynamic assignment model: validation of different measurement methods. Transportation Research Procedia, 27, 1026-1033.

Torrisi, V., Ignaccolo, M., \& Inturri, G. (2018, May). Innovative Transport Systems to Promote Sustainable Mobility: Developing the Model Architecture of a Traffic Control and Supervisor System. In International Conference on Computational Science and Its Applications (pp. 622-638). Springer, Cham.

Torrisi V., Ignaccolo M., Inturri G. (2018). Toward a sustainable mobility through a dynamic real-time traffic monitoring, estimation and forecasting system: The RE.S.E.T. project. Town and Infrastructure Planning for Safety and Urban Quality - Proceedings of the 23rd International Conference on Living and Walking in Cities, LWC 2017, pp. 241-250. 
Torrisi, V., Ignaccolo, M., Inturri, G., (2018). Exploiting ITS technologies through a Traffic Supervisor System to support strategies and actions promoting Sustainable Mobility. In International Conference on Traffic and Transport Engineering (ICTTE) Proceedings, Belgrade (p. 1042-1049).

Trupac, I., Twrdy, E. (2010). More Competitiveness of the Port of Koper through Supply Chain Integration. Promet-Traffic \& Transportation, 22(4).

Verhoeven, P. (2010). A review of port authority functions: Towards a renaissance? Maritime Policy \& Management, 37(3), 247-270.

Viana, M., Hammingh, P., Colette, A., Querol, X., Degraeuwe, B., de Vlieger, I., \& van Aardenne, J. (2014), Impact of maritime transport emissions on coastal air quality in Europe, Atmospheric Environment, 90, 96-105.

Wagner, N. (2017). Identification of the most important sustainability topics in seaports. Logistics and Transport, 34.

Wolff, P. (2004). EU Member State Experiences with Sustainable Development Indicators (Luxembourg: Office for Official Publications of the European Communities).

World Commission on Environment and Development - WCED (1987). Our Common Future; Oxford University Press: New York, NY, USA,

World Shipping Council, [online] Available at: http://www.worldshipping.org/about-the-industry/global-trade/ports. [Accessed 01/03/2019].

UNCTAD (2009). REVIEW OF MARITIME TRANSPORT 2009. [online] https://unctad.org/en/docs/rmt2009_en.pdf [Accessed 04/03/2019]

United Nations. World Urbanization Prospects, 2014. [online] https://esa.un.org/unpd/wup/publications/files/wup2014-highlights.pdf [Accessed 04/03/2019]

\section{Author Contributions}

Investigation and Methodology, Nadia Giuffrida and Vincenza Torrisi; Funding acquisition, Giuseppe Inturri and Matteo Ignaccolo; Supervision, Giuseppe Inturri and Matteo Ignaccolo; Writing - original draft, Nadia Giuffrida and Vincenza Torrisi; Writing - review \& editing, Nadia Giuffrida, Vincenza Torrisi, Giuseppe Inturri and Matteo Ignaccolo.

\section{Acknowledgments}

This work has been partially financed by the University of Catania within the project "Piano della Ricerca Dipartimentale 2016-2018" of the Department of Civil Engineering and Architecture and the project "Piano per la Ricerca 2016-2018 Linea di intervento 2" of the Department of Electric, Electronic and Computer Engineering. The work has been partially financed by the project "THALASSA Technology and materials for safe low consumption and low life cycle cost vessels and crafts" (unique project code CUP B46C18000720005) under the programme "PON Ricerca e Innovazione 2014 - 2020". This study was also supported by the MIUR (Ministry of Education, Universities and Research [Italy]) through a project entitled WEAKI TRANSIT: WEAK-demand areas Innovative TRANsport Shared services for Italian Towns (Project code: 20174ARRHT CUP Code: F74I19001290001), financed with the PRIN 2017 (Research Projects of National Relevance) programme. We authorize the MIUR to reproduce and distribute reprints 
European Transport $\backslash$ Trasporti Europei (2020) Issue 78, Paper $n^{\circ}$ 7, ISSN 1825-3997

for Governmental purposes, notwithstanding any copyright notations thereon. Any opinions, findings and conclusions or recommendations expressed in this material are those of the authors, and do not necessarily reflect the views of the MIUR. 